\title{
Micro and Small Manufacturing Enterprise Growth in Bahir Dar City, Ethiopia
}

\author{
Dejene Fikadie (Msc) \\ Lecturer, Economics Department, Debre Tabor University, Ethiopia
}

\begin{abstract}
This study was aimed to analyze micro and small manufacturing enterprise growth level in Bahir Dar city using cross sectional data collected from 220 randomly selected wood and metal manufacturing enterprises. Primary data was collected by using structured questionnaires. This study tested the relationship between entrepreneur and enterprise characteristics on growth of micro and small manufacturing enterprise. The econometrics result indicated that out of sixteen explanatory variables seven variables were found significant relationship. Such as access to credit, age of owner, sex, enterprise age, initial size of enterprise, location and current financial capital have significant relationship. Access to credit, age of owner, current financial capital and location were positively related to enterprise growth whereas sex, age and size of enterprise were negatively related. Finally, the estimations result shows that old micro and small manufacturing enterprises have less growth. The study concludes that entrepreneur and enterprise characteristics are the determinate of growth level of enterprise. In conclusion, government policy besides an intervention any policy should be evidence-based on entrepreneur and enterprise characteristics target of enterprise growth.
\end{abstract}

Keywords: Micro and Small Enterprise, Growth and Manufacturing

DOI: $10.7176 / \mathrm{DCS} / 11-6-01$

Publication date:June $30^{\text {th }} 2021$

\section{Introduction}

\subsection{Background of the study}

A rise in micro and small enterprise is receiving an increasing attention both in developing and developed country for socio economic development. Predominantly government in developing countries has been made more focus on the establishment of polices on the capacity of micro and small enterprise for industrialization. Supporting micro and small enterprise is one of the pillars, for long term sustainable economic growth and development strategy. This enterprise mostly owned and operating by small capital, low skill requirement, target women and they can absorb growing labor forces at global level. Nevertheless, financial constraints and lack of management skill influence growth of enterprise ( Hassan \& Ahmad, 2016)

In Africa, micro and small enterprise provides potential contribution on economic development and growth of a given nations is well recognized. In developing countries these enterprise plays crucial role towards employment creation, poverty reduction and industrial transformation. Even if, currently they have low performances both from employment creation and capital accumulation in favor of business activates. Not only, the creation of job in micro and small enterprise sufficient, but the creation of productive job in micro and small enterprise it is important to poverty reduction in Africa. Yet, growth and productivity of this sector have not been appropriate mainly in manufacturing sector (Houghton, 2017 ; Reeg, 2015 )

Currently, micro and small enterprise obtain direct support from Ethiopia government in different ways. On average, the performances of these sector is very low and no significant gradual changes from micro to small and medium enterprise (Drbie \& Tilaye, 2013) regarding to growth of urban small manufacturing enterprise critical affected by enterprise characteristics and managerial skill problem such as education level and work experience (Negesso, 2016)

In line with the above objectives of Micro and small enterprise, Amhara National regional state based on the proclamation number 42/1999 has formulated strategy in the region by knowing the contribution of micro and small enterprise for the society of the region such as, create employment opportunity, bring rapid economic growth and produces wide range of goods and services. However, Micro and small enterprise are characterized by low productivity, low level of employment and capital, limited access to credit, lack of business skill and linkage are problem of enterprise in Amhara region (Egziabher \& Demeke, 2007, Cherkose et al ., 2017, Minilek \& Chinnan, 2012)

Correspondingly, According to Gebreeyesus \& Ambachew (2017) baseline survey report in micro and small manufacturing enterprise in Ethiopia from ten large city including Bahir Dar reported that most important factor that affecting the operation and growth of micro and small manufacturing enterprise are lack of working place, lack of access to credit and business supports services, as well the number of employment being created is still lower. The sub sector identified as growth oriented by the Ethiopia government are not attractive further entrepreneurs.

According to Bahir Dar city micro and small enterprise offices (2010) data there are 577 micro and small 
enterprise in manufacturing sector registered officially, which created job only to 1,221 people. But, this indicates the role of Micro and small enterprise into the city regarding to job creation remains much low in manufacturing compared to other sectors such as urban agriculture, trade, construction and services. Many of these micro and small enterprise in manufacturing sector are unable to realize their full potential due to the existences of different factors affecting growth of enterprise. Depending on the local context some factors may be more important than others growth of enterprise (Reeg, 2015). For this reason, there are several factors that may influences growth of micro and small manufacturing enterprise in Bahir Dar city.

In this sense, empirical evidences are very important in identifying the factor that affects growth of manufacturing enterprise. In this study, the effect of entrepreneur and enterprises characteristics on growth level was estimated. Therefore, critical assessment of association factor affecting growth of enterprise is need so as to achieve the contribution their growth to the city's economy by identifying key factor they are facing. Based on the above considerations, this study seeks to investigate micro and small manufacturing enterprise growth level. Along with, by examine factor influencing growth of micro and small manufacturing enterprise in Bahir Dar city.

\section{Literature Review}

\subsection{Definition of Micro and Small Enterprise in Ethiopia}

There is no common familiar definition for micro and small enterprise at international level. Countries have various criteria small, micro and medium enterprise but the objective all most the same. Ethiopia also defines enterprise micro and small based on capital, human power and sector of operation. The definition of micro and small enterprise in Ethiopia it is significantly different from other countries in terms human power and asset of entrepreneur. Micro and small enterprise definition in Ethiopia in table 1.

Table 1: Classification of micro and small enterprise in Ethiopia

\begin{tabular}{lccc}
\hline Types of Enterprise & Sector & Human Power & Capital (asset ) in birr \\
\hline Micro & Industries & $<5$ & $<100,000$ \\
Micro & Services & $<5$ & $<50,000$ \\
Small & Industries & $6-30$ & $<1.5$ million \\
Small & Services & $6-30$ & $<500,000$ \\
\hline
\end{tabular}

Sources (FEMSEA, 2013)

\subsection{Theories of Micro and Small Enterprise Growth}

Various theoretical models have been developed which describe the growth of small businesses. One class of theoretical models focus on the learning process, either active or passive, and the other models refer to the stochastic and deterministic approaches. In the passive learning model a firm enters a market without knowing its own potential growth. Only after entry does the firm start to learn about the distribution of its own profitability based on information from realized profits. By continually updating such learning, the firm decides to expand, contract, or to exit. This learning model states that firms and managers of firms learn about their efficiency once they are established in the industry. Firms expand their activities when managers observe that their estimation of managerial efficiency has understated actual levels of efficiency. As a firm age, the owner's estimation of efficiency becomes more accurate, decreasing the probability that the output will widely differ from one year to another. The implication of this theoretical model is that smaller and younger firms should have higher and more viable growth rates (Liedholm, 2002),

In the active learning model (Goedhuys, M., \& Sleuwaegen, L. (2000), a firm explores its economic environment actively and invests to enhance its growth under competitive pressure from both within and outside the firm. The potential and actual growth changes overtime in response to the outcomes of the firm's own investment, and those of other actors in the same market. According to this model of learning, owners or managers could raise their productivity through formal education and training that increases their endowments

Gupta (2013) there are two set of theories concerning to enterprise growth first one is growth of enterprise is linear and predictable likewise affecting by different factors internal and external factor that can explain growth of enterprise. But, others believe growth is opportunistic and random which means that there are many factors affect growth and no specific factor dominantly affects growth of enterprise. Age and size of enterprise have no effect on growth; all changes are due to chances. However, it disprove by different studies including Evans (1987) argued that age and size of enterprise are potential variables significantly affect enterprise growth. The concepts of growth different from enterprise to enterprise, either growth it can be define in terms of revenue generation or expansion of enterprise. As well it can be measure in qualitative form of growth. In addition, enterprise growth depends on the dream and incentive of entrepreneur.

There is no consistence measurement in growth of enterprise in theories used as objectives of analysis. Some refers employment, profit, value added, turnover and total asset also different theories have not actually defined the parameter of interest. In stochastic growth model suggest that many factor affect growth, therefore, there is no dominate theories in growth of enterprise. Other than growth is the product of an internal process of development 
of an enterprise. There is no agreement for measurements of enterprise growth and determinate factors (Hitchens, 1988)

Gopinath (2012) offered on growth of firm an increase sale, profit and employment at different times refers the most important determinate of firm performances. Firm growth has been considered both theoretically and empirically in different disciplines including economics psychology and entrepreneurship. The inter relationship growth and profitability is more difficult due to mixed empirical result provided by the researcher. From theoretical argument it have causality effect better growth have profitability also profitability leads growth. This means that the more efficient and profitable will have better growth as compare to other. Effective and productive managerial resources determine growth of enterprise. However, various theoretical models has been developed which explain growth of micro and small enterprise, it remains the case that no single accepted enterprise growth model. Enterprise growth is used to explain a development process of enterprise from micro to small and medium to large. The implication of development greater than meaning of enterprise growth but growth is one part of enterprise development.

\subsection{Empirical Studies on Determinates of Micro and Small Enterprise Growth}

According to Reichstein \& Dah (2004) growth of enterprise is not "random walk" functional from to examine growth of enterprise. There are deterministic essential variables that are linked to growth of enterprise. As well there are different variables confirm as explanatory for growth based on the existing empirical studies such as size, age and geographic location.

In addition, Mac (2013) suggested that age and size of micro and small enterprise are determinate only young enterprise growth not for old enterprise. Training and productivity of labor critically affect growth enterprise. The average growths of young micro and small enterprise have extensively above old enterprise. This micro and small enterprise have different variables that critically determine growth and productivity. A number of variables cause affect growth of enterprises directly, indirectly or together.

Heshmati (2001) worked on growth of micro and small firm in expressions of growth employment, sale and asset as measurement. Growth of firm were responsive to functional from and estimation methods. Size and age of firm have no significant effect on sale but positively for employment growth and negatively for assts. Age has negative effect on employment model but positive effect on both asset and sale model.

According to Reichstein \& Dahl (2004) worked out to confirm the firm growth rate explanatory variable such as age, size, geographic location and average annual employment growth rate as a dependent variable. All variable have been significant positive effect on growth of firm with OLS econometrics model. However, entrepreneur characteristics do not analyzed in his model.

Study conducted by Loewe \& Reeg (2015) in three different countries Egypt, Indian and Philippines based on panel data. With Logit model different factors affecting micro and small enterprise such as enterprise age, size, and access to finances, education and human resources developments in terms of training. Except, age and size of enterprise others significantly affect the growth of enterprise.

Studies conducted in Nigeria, micro and small enterprise to analyzed employment creation income generation capacity. Probit regression analysis used both in income and employment model. The ages of enterprise and education level were positively affecting micro and small enterprise to generate employment opportunity. The older ages of business have positive contribution for employment creation. Also education has positive effect on income level of enterprise, but the age of enterprise has negative insignificant effect on income level which is more contradict with other studies (Bowale \& Ilesanmi, 2014)

Heshmati (2001) analyzed the relation between age, size and growth rate of micro and small enterprise in terms of employments creation as measurements of micro and small enterprise growth. The estimations based on different factors controlled including human capital, capital structures, performances and labor market condition. The size of micro and small enterprise has a positive significant relationship, but the age has negative relations with the growth of micro and small enterprise. The size of enterprise measured in the number of employee from enterprise formerly available.

Studies made on the determinate of micro and small enterprise growth in Tigray region Mekelle city, to identify factor affecting the growth of Micro and small enterprise in terms of employment growth. Gender and location of business affect growth of enterprise. The male owner enterprise has better growth than women operating enterprise. The growth of enterprise varies between business operating in home and along main road in commercial centers. enterprise operating along the main road have better growth than others (Tefera et al , 2013).

Mcpherson( 1996) and Alemayehu \& Gecho (2016) worked on to analyze the relation between credit and enterprise growth in terms of employment growth as dependent variable. However, access to credit do not have significant role for growth of enterprise. A significant determinates of the growth of micro and small enterprise is the initial size, age and human capital embodied and unobservable characteristics of enterprise affect growth.

Leza, et al (2016) analyzed the determinate of micro and small enterprise employment growth in Wolaita zone, in multiple linear regression analysis. The study concluded that size of enterprise, education, access to training, 
access to credit, startup capital, vertical and horizontal linkage are the significant determinate for growth of enterprise. Access to training, credit and education has positive significant effect on employment growth of enterprise. But, Age and the size of enterprise are the negative determinates of employment growth of enterprise. It indicate that young micro and small enterprise fast to grow than older enterprise. As well enterprise has vertical linkage from buyer and supplier affects employment growth negatively due to strong competition among enterprise.

The study analyzed by Goshu et al. (2015) on the determinate of micro and small enterprise growth in terms of profitability in Nekemte town through linear regression econometrics model (OLS). The location of enterprise has been positively directly effect on profitability of enterprise due to influencing the demand and supply condition of enterprise. Work experience has positive significant effect on profitability of enterprise. However, education has negative significant effect on profitability of enterprise.

Shibia (2017) worked out to analyze the determinate of micro and small enterprise in Kenya. The change in two years sale volume was as a dependent variable in the model it represent growth of enterprise. Ownership, work experiences and access for credit determined growth of micro and small enterprise positively. As compared to sole proprietorship micro and small enterprise the joint owner micro and small enterprise have better growth.

According to Gezahegn et al (2015) worked on common factor affecting the successes of Micro and small enterprise in Arbaminch Town, Ethiopia. Employment and capital growth are measurement of enterprise performances. Entrepreneur characteristics and other related variables such as size and age of enterprise in the model. Unfortunately, entrepreneur characteristics including, accesses training has not significant effect on the success of micro and small enterprise both on capital and employment growth. Rather, enterprise size and age has significant effect on growth of enterprise with multiple linear regression analysis. The age of enterprise has negative effect both in capital and employment growth of enterprise. But size of enterprise has positive effect on capital and employment growth of enterprise. Increase in number of employees possible to create capital growth and employment opportunity by micro and small enterprise.

According to Hagos et al .(2014) conducted a study on growth of micro and small enterprise in Feresmay town in Ethiopia. Employment growth as measure of enterprise growth with different explanatory variables such as credit, age of owner/manager, education level, initial size of employment, initial capital, working places, work experiences and age of enterprise in econometrics model by OLS estimation method. Ages of enterprise and owner have negatively related growth of enterprise. But, education level, working experiences and credit affect growth positively on the other hand working place, initial size of employment, initial capital have insignificant relation with enterprise growth.

One of the strategies for the reduction of unemployment and poverty especially women is supporting micro and small enterprise. The transformation to medium and large enterprise in the long run is one objectives of government at national level. However, enterprise has slow growth based employment growth of enterprise. Enterprise owned or operated by female has small initial capital and poor capital growth. In addition $23 \%$ of women entrepreneur have lack access to market for expansion of their enterprise the determinate of micro and small enterprises employment growth model. Woman owner enterprise has low employment growth as compare to male owner enterprise. However, another study Chirwa (2004) reported female owned enterprise were rapidly grow in terms of employment than male owned in Malawi. The education level of entrepreneur positively contributes for growth of enterprise ( Worku \& Yifredew, 2017)

\section{Research Methodology}

\subsection{Sample Size Determination and Sampling Techniques}

In order to collect data the number of sample needs to determine initially. The level of precision, level of confidences interval and degree of variability needs to specify during sample size determination (Israel, 1992). This study focused only 493; micro and small manufacturing in Bahir Dar city are which involved into wood and metal manufacturing sector. These 493 micro and small enterprise in wood and metal manufacturing sector are the target population of this study. At $95 \%$ confidences interval and 5\% precision level the number of sample size needs from 493 totals micro and small enterprise in wood and metal manufacturing was 220 . This study applied a simplified formula provided by Yamane (1967) to determine the required sample size at 95\% confidence level, degree of variability $=0.5$ and level of precision $=5 \%$.

$$
n=\frac{N}{1+\mathrm{N}(\mathrm{e}) 2}
$$

Where $\mathrm{n}$ is the sample size, $\mathrm{N}$ is the population size (equal to 493) and $\mathrm{e}$ is the level of precision (equal to $5 \%$ ). The above formula required a minimum of 222 respondents and this study was carried out on 222 respondents. In order to adjusting non- response problem 10 sample enterprise were include.

Micro and small enterprise were stratified in to nine non overlapping strata that are relatively homogenous based on the location. Such stratification was appropriate because the number and characteristics enterprise significantly varies by location. After the stratification of enterprise done by location, next the sampling enterprise stratified by sector into wood and metal within micro and small. Then, a random sample from each sector of these 
strata were selected independently in a number proportional to each sector of the strata size by comparing to the total population. After that, 101 and 121 micro and small enterprise were randomly selected from wood and metal manufacturing sector respectively. When the sample of strata added it gives total sample size. Finally, the respondent was randomly selected from each sector of nine sub cities with the help of simple random sampling in lottery method based on an equal probability system in each sector from nine sub cities.

\subsection{Data Type, Sources and Methods of Collection}

This study was depending on both primary and secondary data. The primary data were collected through structured questionnaires. In order to meet the objective the study detail information were collected such as characteristics of the operates of micro and small enterprise including age, education level, work experiences, and including the profile of enterprise years of establishment, initial capital, current capital, numbers of employees at starting and current, access to training, credit, linkage and other related information important for analysis were collected. The structured questionnaires were arranged both in Amharic and English language. Two supervisors and eight enumerators were selected to collect the relevant data from a sample of micro and small enterprise. The enumerators were taken one day training by the researcher related to data collection. Secondary data were obtained from Bahir Dar city micro and small enterprise development offices including list of enterprise. The objectives of the research have been informed to the owner or manager of enterprise in order to get reliable data.

\subsection{Methods of Data Analysis}

\subsubsection{Growth of Enterprise Model Specification}

There is no single common measurement of enterprise growth from the literature. But, different researcher applying commonly such as total assets, sale volume, total capital, employment variation and profit are different times as measurement of enterprises growth. Measuring micro and small enterprises growth in terms of employment and sale recommend by researchers. Taking employment growth as measurement of enterprise growth is consistence as employment creation is one objective of policy attention of micro and small enterprise development for developing countries like Ethiopia having youth unemployed (Mohammed , 2014). In order to measure growth of micro and small manufacturing enterprise employment size was appropriate for this research developed by (Evans, 1987) and adopted by different researcher such as (Tefera et al , 2013; Alemayehu \& Gecho ,2016; Leza,et al ,2016 ;Hagos et al. , 2014; Abay, 2014). Applying employment growth of enterprise is similar to sale growth of enterprise measurement due to employment and sale growth highly correlated. In the studies of enterprise growth the above researcher used two econometrics model Logit and multiple linear regressions in order to estimate enterprise growth. But, there are no logical reasons make growth categories variable growing and none growing to use Logit model. In this analysis, regression model of Ordinary Least Square (OLS) method is specified as follow because the value of growth ranges from zero, negative and positive value. The regression analysis used to test whether or not basic independent variables relate to dependent variable through including all econometrics diagnostic tests (Greene, 2002)

$$
g r=\frac{\ln E t \cdot \ln E t}{\text { Etage }}=Y i \quad---------------(3)
$$

Where, $g r=Y i$ mean that growth rate of employment,

$L n E t \cdot$. the natural logarithm of current employment

$L n E t=$ natural logarithm of initial employment size

Etage $=$ the age of micro and small manufacturing enterprise.

$\ln Y i=\beta o+\beta 1$ ageow $+\beta 2$ gedr $+\beta 3$ worke $+\beta 4$ tranig $+\beta 5$ eduction $+\beta 6$ Eeage +

$\beta 7$ esize $+\beta 8$ setor $+\beta$ lncintial $+\beta 10$ lncrret $+\beta 11$ credit $+\beta 12$ workpl $+\beta 13$ owners +

$\beta 14$ locatio $+\beta 15$ vrti $+\beta 16$ hrzo + Ui---------------3.1

\subsection{Description of Variables used in Econometrics model}

Enterprise Employment Growth (Yi): It is dependent variables of the model used for as enterprise growth and explains by independent variables including in the model are listed below. 


\begin{tabular}{|c|c|c|}
\hline Variable name & Type & Definition \\
\hline Sex & Dummy & Sex of entrepreneur it takes value 1 for male 0 otherwise \\
\hline Age & Continuous & It is the ages of entrepreneur in years \\
\hline Experiences & Continuous & $\begin{array}{l}\text { The number of years spending related to this business including past } \\
\text { experiences. }\end{array}$ \\
\hline Training & Dummy & $\begin{array}{l}\text { An entrepreneur of enterprise access to training related to business activity. } \\
\text { It takes dummy value } 1 \text { yes } 0 \text { otherwise }\end{array}$ \\
\hline Education & Continuous & It measure in year of schooling of owner of enterprise. \\
\hline Enterprise age & Continuous & Age of enterprise measured in number of years since the startup of business \\
\hline Esize & Continuous & $\begin{array}{l}\text { The size of enterprise measures in terms of the number of labor employed in } \\
\text { manufacturing enterprise when enterprises established. }\end{array}$ \\
\hline Sector & Dummy & There are two sector wood and metal manufacturing 1 for metal 0 otherwise \\
\hline lnCintial & Continuous & $\begin{array}{l}\text { The amount financial capital when enterprises start up to practice working } \\
\text { activity. }\end{array}$ \\
\hline $\operatorname{lnCurrtc}$ & Continuous & $\begin{array}{l}\text { The amount of total financial capital current available for enterprises to } \\
\text { continue business. }\end{array}$ \\
\hline Credit & Dummy & $\begin{array}{l}\text { When enterprises access to finances to run their enterprise. it takes dummy } \\
\text { value } 1 \text { yes access credit } 0 \text { otherwise }\end{array}$ \\
\hline Workplace & Dummy & It takes dummy value 1 if it have own working places, 0 otherwise \\
\hline Ownership & Dummy & It takes dummy value 1 for sole proprietorship 0 otherwise \\
\hline Location & Dummy & It takes dummy value 1 working in close to in front of road 0 otherwise \\
\hline Vertical linkage & Dummy & It has dummy value 1 if enterprise has vertical linkage 0 otherwise \\
\hline $\begin{array}{l}\text { Horizontal } \\
\text { linkage }\end{array}$ & Dummy & It takes dummy value 1 if enterprise has horizontal linkage 0 otherwise. \\
\hline
\end{tabular}

\section{Data Presentation and Analysis}

In this section both the descriptive and econometrics results are presented and discussed. The sample enterprise and entrepreneur characteristics are presented through different statistics tools such as means, standard deviation and percentages. First, the entrepreneur characteristics of respondents were presented and analyzed followed by the characteristics of enterprises. Finally, econometrics model result of growth was reported. A total of 232 surveys were distributed and 220 were properly filled and collected. All the analysis below is based on this group of respondents.

\subsection{Result of Descriptive Statistics}

\subsubsection{Characteristics of Entrepreneur}

Table 2 represents the entrepreneur gender, age, education level, experiences and training exposure of respondents. Among the sampled enterprises included in the analysis, $88.18 \%$ were male while $11.82 \%$ were female entrepreneur in Bahir Dar city micro and small manufacturing sector. This indicates that the participation of female on micro and small manufacturing sector were relatively low compared to male. In addition, compared to other countries the participation of women on micro and small manufacturing in Botswana were $71 \%$ (Daniels \& Fisseha, 1992).

Concerning to access to training related to the current working activates $64.09 \%$ of the respondent have received training related to their duty whereas $35.91 \%$ didn't receive training. This result show that more than half of entrepreneur have accessed training (Table 2).

Table 2: Entrepreneur Gender and Accessed to Training

\begin{tabular}{lll}
\hline Gender & Frequency & Percent \\
\hline Male & 194 & 88.18 \\
Female & 26 & 11.82 \\
Total & 220 & 100 \\
Accessed to Training & & \\
Yes & 79 & 64.09 \\
No & 141 & 35.91 \\
\hline Total & 220 & 100 \\
\hline
\end{tabular}

Sources: survey result

The evidence table 3 shows that, the average age of business entrepreneur is nearly 33 years old, maximum age of 55 with minimum of 22 years old. This indicates that on average young entrepreneur are engaged in manufacturing sector. Also one of the objectives of micro and small manufacturing sector is creating job opportunity for the young labor forces is current government policy agenda. 
The sample entrepreneur average years of education were 9 years of schooling within 17 year maximum of year of education and minimum of 0 . The results showed that majority of the sampled entrepreneur have completed primary education level.

Working experience was measured by the number of years entrepreneur had spent related to current engagement. The mean value of work experience is about 7 years. The lowest and the highest years of work experience of entrepreneur are 1 and 16 respectively.

Table 3: Entrepreneur Demographic Profile

\begin{tabular}{clllll}
\hline Entrepreneur characteristics & Obs. & Mean & Std. Dev. & Min & Max \\
\hline Age & 220 & 33 & 6.94 & 22 & 55 \\
Year of education & 220 & 9 & 3.167 & 0 & 17 \\
Experiences & 220 & 7 & 4.36 & 1 & 16 \\
\hline
\end{tabular}

Sources: survey result

\subsubsection{Characteristics of the Enterprises}

\section{Business Sector}

As stated in the previous chapter, by the nature of micro and small manufacturing enterprises the sample enterprises were working in two sectors in wood and metal manufacturing sector $45.54 \%$ and $54.55 \%$ respectively. Concerning to the form of micro and small enterprise group, $51.36 \%$ were micro while $48.64 \%$ small manufacturing enterprises in wood and metal manufacturing (Table 4).

Table 4: Sector Distribution of Manufacturing Enterprises.

\begin{tabular}{|c|c|c|}
\hline Manufacturing sector & Frequency & Percent \\
\hline Metal & 100 & 45.45 \\
\hline Wood & 120 & 54.55 \\
\hline Total & 220 & 100 \\
\hline \multicolumn{3}{|l|}{ Group of Enterprise } \\
\hline Micro & 113 & 51.36 \\
\hline Small & 107 & 48.64 \\
\hline Total & 220 & 100 \\
\hline
\end{tabular}

Sources: survey result

Table 5: Descriptive Statistics of Some Enterprises Characteristics

\begin{tabular}{llllll}
\hline Enterprise characteristics & Obs. & Mean & Std. Deviation & Min & Max \\
\hline Enterprise age & 220 & 4.94 & 3.008536 & 1 & 15 \\
Number of labor at start up & 220 & 2.95 & 1.338612 & 1 & 8 \\
Employment currently & 220 & 4.90 & 1.848653 & 2 & 12 \\
Financial capital at start up & 220 & 33,200 & $50,378.32$ & 2500 & 88,000 \\
Current financial capital & 220 & 88,977 & $73,704.31$ & 30,000 & 200,000 \\
\hline
\end{tabular}

Sources: survey result

As show in table 5, the sample enterprises in this study have an average age of 4.94 years. The amount of startup financial capital was an average of 33,200 Birr and currently 88,977 Birr. The evidence in table shows that the average number of workers at start-up and current time from sample Micro and small enterprise are 2.95 and 4.9 respectively; it range varies from 1 to 8 for start-up employment and from 1 to 12 for employment at currenttime. This indicates that the mean of the employment currently exceeds that of employment at start up by 1.95 employees.

\subsubsection{Form of Enterprise Ownership Structure}

The survey result in table 6 showed that the distribution enterprise by the ownership structures. Accordingly, 78.18\% enterprises were sole proprietorship business structure and $21.82 \%$ are cooperatives. This shows that majority of manufacturing enterprise owned by sole proprietorship business ownership structures.

Table 6: Ownerships Structures of Enterprises

\begin{tabular}{lll}
\hline Ownership & Frequency & Percent \\
\hline Sole proprietorship & 172 & 78.18 \\
Cooperatives enterprises & 48 & 21.82 \\
\hline Total & 220 & 100 \\
\hline
\end{tabular}

Sources: survey result

\subsubsection{Enterprise Accesses to Credit}

According to the statistics presented in table 4.6, about $42.73 \%$ micro and small manufacturing enterprise accessed credit to run the current business activity from different sources while $42.23 \%$ did not access credit. Lack of access to credit most the time regarded as the basic problem of micro and small enterprise in developing countries due to high collaterals requirements by formal financial institution. This is true in most African countries. It is also exact that financing of private sector is in problem due to bank charge high interest rate to improve profitability and 
reduce operating cost and limited credit for Micro and small enterprise.

Table 7: Enterprises Accessed Financial Credit

\begin{tabular}{lll}
\hline Received to credit & Frequency & Percent \\
\hline Yes & 94 & 42.73 \\
No & 126 & 57.27 \\
Total & 220 & 100 \\
\hline
\end{tabular}

Sources: survey result

\subsubsection{Work places and Location of Enterprise}

Regarding to working places and location of enterprise, $67.73 \%$ Micro and small enterprise were working in front of the road while other $32.27 \%$ of micro and small manufacturing working at home. In relation to working places of enterprises, $35.91 \%$ of enterprises have not their own working places while $64.09 \%$ have not own working places. Thus, all enterprises need working places to produces as well as supply their goods and services to customers (Table 8).

Table 8: Enterprise Work Places and Location

\begin{tabular}{lll}
\hline Working Location & Frequency & Percent \\
\hline Operating front to Road & 149 & 67.73 \\
Not front to Road & 71 & 32.27 \\
Total & 220 & 100 \\
Own working places & & \\
Yes & 141 & 64.09 \\
No & 79 & 35.91 \\
Total & 220 & 100 \\
\hline
\end{tabular}

Source: survey result

\subsubsection{Vertical and horizontal linkage of Enterprise}

As can be evidenced below in table 9, from the sampled enterprises regarding to vertical and horizontal linkage, vertical linkage of micro and small enterprises have subcontracting from of relation with input supplier in the business activity $54.55 \%$ have linkage from input supplier the rest $45.54 \%$ do not have linkage at all. Vertical linkage can facilitate Micro and small enterprise growth by expanding enterprise business opportunity and improving productivity.

Concerning the horizontal linkage, enterprises have cooperation or not with other enterprise engaged in similar activity. From the sample enterprises $66.36 \%$ have cooperation among related enterprises and $33.64 \%$ have no cooperation.

As global economy today, there are different ways of linkage including vertical and horizontal linkages enterprises have greater role on performances of micro and small enterprise in manufacturing sector. Linkage of enterprises plays greater function on growth and efficiency level of enterprise. The market linkage of micro and small enterprises are more limited they have only direct relation with customers. The majority of micro and small enterprises in Africa sell their product directly to consumers. Market linkage with other enterprise significantly limited micro and small enterprise (Caroline \& Reeg, 2015)

Table 9: Linkage of Enterprise

\begin{tabular}{lllll}
\hline Linkage of Enterprise & Frequency and percent & Yes & No & Total \\
\hline Vertical linkage & Frequency & 120 & 100 & 220 \\
& Percent & 54.55 & 45.54 & 100 \\
Horizontal linkage & Frequency & 146 & 74 & 220 \\
& Percent & 66.36 & 33.64 & 100
\end{tabular}

Sources : survey result

\subsection{Growth of Manufacturing Enterprise}

According to table 10 average annual employment growth of micro and small enterprise in wood and metal manufacturing sector have mean of 0.397 with maximum growth 2 and minimum growth of -1.33 . The annual change in job per enterprise is a positive 0.397 it indicates on average each manufacturing enterprise increased at the rate of 0.397 people in terms of employment annually. The growth of employment have no much varied by sector, wood manufacturing sector have mean growth of 0.37 and 0.42 in metal manufacturing sector growth annually. 
Table 10: Employment Growth by Sector and Overall Enterprise

\begin{tabular}{llllll}
\hline Sector & Obs. & Mean & Std. Dev. & Min & Max \\
\hline Wood manufacturing & 100 & .376 & .456 & -1.33 & 1.5 \\
Metal manufacturing & 120 & .426 & .445 & -1 & 2 \\
Overall manufacturing & 220 & .397 & .450 & -1.33 & 2 \\
\hline
\end{tabular}

Sources: survey result

Table 11: Frequency Distribution of Enterprise Employment Growth level

\begin{tabular}{lll}
\hline Enterprise Growth level & Frequency & Percent \\
\hline Positive Growth & 176 & 80 \\
Zero Growth & 30 & 13.64 \\
Negative Growth & 14 & 6.36 \\
\hline Total & 220 & 100 \\
\hline
\end{tabular}

Sources: survey result

According to the sampled enterprise in table 11, the growth of enterprise calculated as the differences between the current and initial employment divided by age of enterprise. Micro and small enterprise have different level of growth positive, zero and negative. The highest $80 \%$ of micro and small manufacturing enterprise have positive employment growth and $13.64 \%$ of Micro and small enterprise have zero growth. However, $(6.36 \%)$ micro and small manufacturing enterprise have negative employment growth.

\subsubsection{Growth of Enterprise by Gender}

Regarding to growth of enterprise by gender table 4.11, Micro and small enterprise of the two sector of manufacturing dominated by male entrepreneur and average employment growth is 0.37 whereas the average growth of female entrepreneur is 0.56 . At the same time, the minimum growth of female owner enterprises is 0 and -1.33 for male (table 12)

Table 12: Employment Growth by Gender

\begin{tabular}{llllll}
\hline Gender & Obs. & Mean & Std. Dev. & Min & Max \\
\hline Male & 194 & .373 & .453 & -1.33 & 2 \\
Female & 26 & .566 & .389 & 0 & 1.333 \\
\hline
\end{tabular}

Source: survey result.

\section{Growth of Enterprise}

In order to measure growth of micro and small enterprise multiple regressions is used to analyze the annual growth of employment. The growth of employment was dependent variable and also a proxy measure of enterprise growth. To identify the relationship growth of enterprise with entrepreneur and enterprise characteristics were incorporated in the model. The stata 13 software applications were used.

Before econometrics regression analysis takes places, this study considered various econometrics assumptions and diagnostic tests which can affect consistent of the model applied (OLS). In econometrics regression model diagnostic tests such as testing of normality of residuals, multicollinearity, Heteroscedasticity, model specification, and endogeneity were considered in this study.

Regarding to model specification and Heteroscedasticity test Ramsey's and Breusch-Pagen were employed the result showed that no problem see appendix 3. Multicollinearity test with variance inflation factor (VIF) showed that no multicollinearity problem see appendix 4 . The distribution of residual have normal distribution curve in histogram see in appendix 5. The test used to check for endogeneity problem of variables by comparing instrumental variables estimates to ordinary least square (OLS) estimates. There is no endogeneity problem in the model all method gives the similar result see appendix 6 and 7. Finally the overall goodness of fit of the model at less than $1 \%$ significances level through $\mathrm{F}$ test.

\subsubsection{Econometric Result and Discussion}

Table 13, presents the estimate result of enterprise growth of the OLS estimation result of multiple regression used to determine the growth of micro and small manufacturing enterprise in Bahir Dar city. The $\mathrm{R}^{2}$ value of $21 \%$ indicates that $21 \%$ variation in growth of micro and small enterprise in manufacturing sector enterprises are explained by the explanatory variable used in the model. Generally, seven variables out of sixteen included in the model have significant relationship with growth of micro and small manufacturing enterprise.

The determinates of enterprise growth includes in the model which were statistically significant related to entrepreneur and enterprise characteristics such as age, sex, location, credit, size of enterprise, age of enterprise and current financial capital are statically significant at $1 \%, 5 \%$ and $10 \%$ level of significances. Other variables education, experiences, training, sector, work place, initial capital, ownership structure, vertical and horizontal linkage are statistically insignificant for micro and small manufacturing enterprise growth.

Gender of entrepreneur has significant relationship on growth of enterprise being male have negative relationship to employment growth of enterprise. There is no clear empirical evidence the effect of gender on growth of micro and small enterprise there is only mixed result from the literature. According to Worku \& 
Yifredew, (2017); Tefera et al , (2013) being female have greater probability to fail growth and male entrepreneur have better growth than female. This study result contradicted with above finding but consistent with Adam (2014) ; Chirwa (2004) the growth of female owned enterprise has faster than male owned enterprise. By confirming the results of descriptive statistics it has growth differences among owner enterprise minimum growth is 0 and -1.33 female and male respectively.

The age of entrepreneur have positively significant effect on growth of enterprise at $10 \%$ level of significances. This indicates that young owner entrepreneur have lower employment growth as compared to old age entrepreneur. Based on Hagos et al. (2014) study age have negative effect on growth of enterprises. However in this study, age owner/ manager have positive effect on growth of enterprise the main justification age have positive relationship may be due to young entrepreneur have financial constraints for startup capital and do not have collateral to take credit from different financial institution. In addition, this result also seems logical the older the age of owner /manager of enterprise the more the owners are familiar in business working activity and accumulated resources. This result finding is consistent with (Worku \& Yifredew, 2017)

Different previous theoretical and econometrics model have been given different possible explanation the relationship between age of enterprise and growth. The regression result shows that the growth of enterprise affected by age at $1 \%$ level of significances. The main possible explanations for this result may be older enterprise fail to invest the existing modern technology and hindering productivity relative to young enterprise. An additional possible reason for this result could be due to sub optimal use of resources found in old manufacturing enterprise or diseconomies of scale happed. It show that young micro and small enterprise fast to grow than older enterprise. Age of enterprise has an inverse relation with growth of enterprise and this result has been empirically supported by many studies (Reichstein \& Dahl, 2004; Heshmati ,2001; Hagos et al., 2014; Evans, 1987) . But, this finding contradicts with (Bowale \& Ilesanmi, 2014) the older ages of business have the higher employment creation than young enterprise.

Size of enterprises was significant determinate of enterprises growth at $1 \%$ level of significances. Size defined as the number of employee initial when enterprise established. This implies that enterprise growth decreases with enterprise size. The possible explanation for this result may be an additional employment of labor to fixed capital equipment leads a reduction of productivity with diminishing marginal return. The initial size of enterprise have inverse relation with growth at one percent level of significance similar finding are reported by other researchers ( Leza et al ,2016 ;Mcpherson, 1996). The finding contras to Loewe \& Reeg (2015) size of enterprise have not significant relationship with growth.

Accessed to credit has positively significant effect on growth of micro and small manufacturing enterprise at $10 \%$ level of significances. This result indicates that Micro and small enterprise accessed to credit have high possibility on growth of enterprise consistent with Loewe \& Reeg (2015). According Michael et al. (2010) access to finances were not the significant determinate of enterprise growth this result contradicted with negative effect (Abay et al , 2014) this may be the fact that credit may not be properly used. This may be true related to enterprise need working financial capital to purchased input credit has significant positive relation in this study.

Operating locations of enterprise have positive significant effect on growth of enterprise at $10 \%$ level of significances. Micro and small enterprise that are working in front of road have higher probability of growth as compared to others. This may be reason behind due to providing their goods and services to consumers' directly in very simple way. This result consistent with (Tefera, et al. , 2013;Alemayehu \& Gecho, 2016).

There was positively significant relationship between current financial capital and enterprise growth. This is in line with the theoretical explanations of financial availability and performances of enterprise. Availability financial capital is one necessary mechanism for growth of enterprise to purchase input and payment for worker salaries. This result have similar finding from (Adam, 2014) 
Table 1: Econometrics Model Regression Result of Enterprise Growth Determinates

\begin{tabular}{ll}
\hline Variables & Coefficient \\
\hline Sex & $-0.210^{* *}(0.032)$ \\
Age & $0.0112^{*}(0.044)$ \\
Education & $-0.00308(0.705)$ \\
Experiences & $-0.00176(0.570)$ \\
Training & $0.0630(0.332)$ \\
Sector & $-0.00155(0.864)$ \\
Eage & $-0.0428^{* * *}((0.002)$ \\
Size & $-0.122^{* * *}(0.000)$ \\
Ownership & $0.0383 \quad(0.644)$ \\
Credit & $0.116^{*}(0.073)$ \\
Work places & $-0.00404(0.953)$ \\
Location & $0.117 * \quad(0.061)$ \\
Vertical linkage & $0.024 \quad(0.714)$ \\
Horizontal linkage & $0.0578 \quad(0.396)$ \\
initial capital & $-0.0281 \quad(0.034)$ \\
lncurrent capital & $0.159 *(0.534)$ \\
Constant & $-0.810 \quad(0.284)$ \\
Observations & 220 \\
R-squared & $0.218 \quad$ \\
\hline \multicolumn{1}{c}{ Sources: estimation result } & $* * * \mathrm{p}<0.01, * * \mathrm{p}<0.05, * \mathrm{p}<0.1$ \\
&
\end{tabular}

\section{Conclusion and Policy Implication}

The main objective of this study was to investigate growth level of micro and small manufacturing enterprise in Bahir Dar city. A one month cross-sectional data was collected from sample of 120 and 100 observations in wood and metal manufacturing enterprises respectively. In this study, different econometric model and descriptive statistics were used to estimate data analysis.

In the descriptive statistics growth of enterprise have positive, negative and zero employment growth in wood and metal manufacturing. The highest $80 \%$ of micro and small manufacturing enterprise have positive employment growth and $13.64 \%$ of Micro and small enterprise have zero growth no growth at all. However, $6.36 \%$ micro and small manufacturing enterprise have negative employment growth. The average growth of wood and metal micro and small manufacturing enterprise was positive equal to 0.397 .

In this study formally tested the relationship between entrepreneur and enterprise characteristics with employment growth. Sixteen explanatory variables include in OLS econometrics model only seven variables have statistically significant relationship with employment growth of enterprise. Gender, age of entrepreneur, enterprise age, initial size, credit, location, and current financial capital were statistically significant at $1 \%, 5 \%$ and $10 \%$. Age of entrepreneur, credit, location, and current financial capital were positively related growth of enterprise. Both initial size and age of enterprise are negatively related to growth. Larger and older enterprises grow more slowly than young and smeller manufacturing enterprise. On the other hand, education, training, experiences, sector, work place, ownership, initial capital, vertical linkage and horizontal linkage were found insignificant relationship of enterprise growth. Finally, entrepreneur and enterprise characteristics have different relationship with growth level of micro and small manufacturing enterprise.

Based on the finding of this study, the following policy implication were forward to concerned bodies government, owner of enterprise and other responsible organization on growth level of micro and small manufacturing enterprise in Bair Dar city. Regarding to growth of micro and small manufacturing enterprise improve access to credit and accessibility of current financial capital should be supplemented by different financial institution.

The operating location of enterprise also has positive significant relationship. Enterprise operating in front of road has better growth. Therefore, attentions have to be given with try to create cluster design of enterprise working area. Cluster development for micro and small enterprise facilitate collaboration with sharing of technological progress among enterprise, also it is important to afford infrastructures. In conclusion, government policy and intervention should be evidence-based on entrepreneur and enterprise characteristics within a target of manufacturing enterprise growth level.

\section{Reference}

Adam, M. (2014). Constraints and Growth Potentials of Micro and Small Enterprises : Case from Mekelle City, 5(24), 133-140. 
Alemayehu, D., \& Gecho, Y. (2016). Determinants of Micro and Small Enterprises Growth : The Case of Durame Town, Kembata Tembaro Zone , Southern Nations and Nationalities and Peoples Region , 5(5), 161-175. https://doi.org/10.11648/j.ijber.20160505.15

Bahir Dar city, (2010) Micro and Small Enterprise Offices Data

Berhanu Kuma et. (2017). Determinants of employment growth of micro and small enterprises in, (January).

Bowale, K. E., \& Ilesanmi, A. O. (2014). Determinants of Factors Influencing Capacity of Small and Medium Enterprises ( SMEs ) in Employment Creation in Lagos State, Nigeria, 5(2). https://doi.org/10.5430/ijfr.v5n2p133

Cherkos, T., Zegeye, M., Tilahun, S., \& Avvari, M. (2017). Examining significant factors in micro and small enterprises performance: case study in Amhara region, Ethiopia. Journal of Industrial Engineering International. https://doi.org/10.1007/s40092-017-0221-y

Chirwa, E. W. (2004). Gender and Performance of Micro and Small Enterprises in, (March), 1-27.

Drbie, M., \& Tilaye, M. B. A. (2013). Deterrents to the Success of Micro and Small Enterprises. MUDC , 2013 ), the licensing and supervision of micro finan, 5(2), 1-33.

Egziabher, T. G., \& Demeke, M. (2007). Micro and small entepries in Small towns , Amhara region , Ethiopia :, (January 2007), 79-111.

Evans, D. S. (1987). Tests of Alternative Theories of Firm Growth, 95(4), 657-674.

Gebreeyesus, M., \& Ambachew, A. (2017). Baseline Survey Report: Main Features of manufacturing MSEs in Ethiopia.

Goedhuys, M. , \& Sleuwaegen, L. , (1999). Barriers to growth of firms in developing countries: evidence from Burundi. In: Audretsch, D.B., Thurik, R. (Eds.), Innovation, Industry Evolution and Employment. Cambridge Univ. Press, Cambridge, UK, pp. $297-314$.

Gezahegn, A., Zewdie, S., \& Amentie, C. (2015). Factors Determining the Success of Micro and Small Enterprises in Ethiopia ( The Case of Arbaminch Town ), 69-76.

Gopinath, R. C. (2012). Understanding the determinants of firm growth understanding the determinants of firm growth, (June).

Goshu, F., \& Mba, F. (2015). Determinants of Micro and Small Enterprises Growth in Ethiopia: The Case of Nekemte Town of Oromia Region, Ethiopia, 7(13), 92-105.

Greene. (2002). Econometric analysis.

Growth and Transformation Plan Annual Progress Report (2014). Federal Democratic Republic

of Ethiopia Growth and Transformation Plan Annual Progress Report for F . Y . 2012 / 13,

Gupta, P. D., Guha, S., \& Krishnaswami, S. S. (2013). Firm growth and its determinants, 1-14..

Hagos, H. A. (2014). Determinants of Micro and Small Enterprises Growth in Rural Area: Evidence from Feresmay Town, 5(19), 68-79.

Hassan, T., \& Ahmad, B. (2016). International Journal of Economics \& The Role of Micro Enterprises in Employment and Income Generation: A Case Study of Timergara City Dir ( L ) Pakistan, 5(2). https://doi.org/10.4172/2162-6359.1000318

Heshmati, A. (2001). On the Growth of Micro and Small Firms : Evidence from Sweden, 213-228.

Hitchens. (1988). Alternative theories of small-firm growth : a critical review, 20, 1365-1383.

Israel, G. D. (1992). Determining Sample Size 1, (November), 1-5.

Minilek Kefale and K. P. M Chinnan (2012). Employment growth and challenges in small and micro enterprises Woldiya , North East Amhara region, Ethiopia, 1(April), 21-26.

Leza, T., Rajan, S., \& Kuma, B. (2016). Determinants of Product Diversification Among Micro and Small Enterprises in Wolaita Zone, Ethiopia: An Econometric Analysis, 16(4).

Liedholm, Carl. 2002. "Small Firm Dynamics: Evidence from Africa and Latin America." Small Business Economics 18, nos. 1-3: 225-40

Loewe, M., \& Reeg, C. (2015). The Entrepreneur Makes a Difference : Evidence on MSE Upgrading Factors from Egypt , India , and the Philippines, 66, 118-130. https://doi.org/10.1016/j.worlddev.2014.08.005

Mac, P. (2013). The influence of age on SMEs growth determinants: empirical evidence, 249-272. https://doi.org/10.1007/s11187-011-9363-2

Mcpherson, M. A. (1996). Access to Finance and Small Enterprise Growth : Evidence from East Java Author ( s ): Michael A . McPherson and Jeffrey J . Rous Source: The Journal of Developing Areas, Vol . 43 , No . 2 ( Spring , 2010 ), pp . 159-172 Published by : College of Busines, 43(2), 159-172.

Negesso, K. D. (2016). Growth Determinants of Urban Small Manufacturing Enterprises of Oromia Regional State, Ethiopia, 6(11), 338-348.

Plan, Gtp, II. (2016). Federal Democratic Republic of Ethiopia Volume I : Main Text, I(Gtp Ii).

Reeg, C. (2015). Micro and Small Enterprises as Drivers for Job Creation and Decent Work.

Reichstein, T., \& Dahl, M. S. (2004). Are Firm Growth Rates Random? Analysing Patterns and Dependencies, 18(2), 225-246. https://doi.org/10.1080/0269217042000186705 
Shibia, A. G. (2017). Determinants of micro and small enterprises growth in Kenya. https://doi.org/10.1108/JSBED-07-2016-0118

Tefera, H., Gebremichael, A., \& Abera, N. (2013). Growth Determinants of Micro and Small Enterprises: Evidence, 4(9).

Worku, I., \& Yifredew, S. (2017). working paper 2017-19, (March) 